\title{
The Competition between Legal Orders
}

\author{
Anne Peters ${ }^{1,2}$ \\ ${ }^{1}$ Max Planck Institute for Comparative Public Law and International Law, Heidelberg, Germany \\ ${ }^{2}$ International Law and Constitutional Law at the University of Basel, Switzerland \\ Correspondence: Anne Peters, Im Neuenheimer Feld 535, D-69120 Heidelberg, Germany. E-mail: \\ apeters-office@mpil.de
}

Received: August 25, 2013 Accepted: October 8, 2013 Online Published: April 15, 2014

doi:10.5539/ilr.v3n1p45 URL: http://dx.doi.org/10.5539/ilr.v3n1p45

\begin{abstract}
This paper asks two questions. The first is an analytical one: does the reconstruction of the sovereign activity of law-making and legal reform as a competitive bid have an analytical benefit on which doctrinal insights in particular can build? The second question is a normative one: should the competitive paradigm serve as a normative guideline for the legislator?

The first question is answered with a "yes, but ...". The reconstruction of legal reform as "competition" on a market opens up a new perspective. A variety of different law-selection mechanisms are at work in the tripolar relationship between persons subject to law ("customers") and competing legal systems (or orders). But the competitive cycle is often interrupted by weak selection pressure and selection inaccuracy.

The answer to the second, normative question is developed with a view to five legal principles: liberty, equality, democracy, the social principle, and the public interest. The competition between legal systems partly undermines those principles. This finding suggests that this competition must be adequately framed by a legal meta order. That meta order should, inter alia, ban unfair regulatory practices, establish rules of international cooperation, harmonise some procedures, and it should guarantee respect for some inalienable principles.
\end{abstract}

Keywords: law market, choice of law, voice and exit, race to the bottom, public interest, harmful tax competition, normative dumping

\section{Introduction}

In the age of globalisation, competition between Nation States is perceived sharply. The Davos World Economic Forum, the annual meeting between top executives of global companies and politicians, regularly publishes "Global Competitiveness Reports". These reports identify various factors of the national legal systems which inhibit or promote business activity: labour legislation, tax rates and tax regulations, foreign-exchange regulations, property rights, judicial independence, reliability of police services and protection of minority shareholders' interests, and on this basis the reports establish a ranking of the countries. ${ }^{1}$

Such rankings prompt countries to actively advertise their own legal system. Under the heading "Law Made in Germany", a brochure published by Germany's Federal Chamber of Civil Law Notaries in conjunction with other associations of the legal profession and with a foreword by the Federal Minister of Justice, promoted German law with the catchwords "global - effective - cost-efficient." 2 The publication extols the benefits of codification, praises the lack of cross-examination and punitive damages and stresses the legal certainty created with the German Land Register and Commercial Register. The German advertising brochure reacted to the English publication "England and Wales: The Jurisdiction of Choice", published by the Law Society of England

\footnotetext{
${ }^{1}$ According to the report for 2012/2013, Switzerland ranks first, the Netherlands occupy rank 5, followed by Germany (6) and the U.S. (7) (WEF. Global Competitiveness Report, 2009-2010 (http://www.weforum.org/reports/global-competitiveness-report-2012-2013). The World Bank, too, publishes so-called "Doing Business" reports on a regular basis which allow for the comparison of legal provisions of nearly all States in the world, the latest report is benchmarked as of June 2012. http://www.doingbusiness.org/rankings.

2 The Federal Chamber of German Civil Law Notaries (Bundesnotarkammer), the German Federal Bar (Bundesrechtsanwaltskammer), the German Bar Association (Deutscher Anwaltverein), the German Notaries' Association (Deutscher Notarverein) and the German Judges Association (Deutscher Richterbund). (Eds.). Law Made in Germany. http://www.lawmadeingermany.de.
} 
and Wales, with a foreword by the British Secretary of State for Justice. ${ }^{3}$ These PR campaigns are reminiscent of the traditional so-called "systems competition" between common law and civil law.

\section{State versus Market}

PR activities of that type have sparked a controversy in legal scholarship. ${ }^{4}$ The fundamental criticism is that the mode of interaction called competition (see for the meaning of "competition" below section 3 ) is irreconcilable with the organisational form of the State. Some legal scholars claim that it would be a categorical mistake to apply the concept of competition to States, because - so the argument runs - the organising principle of "sovereignty" is diametrically opposed to the organising principle of "competition". From that perspective, law is simply no product suitable to be placed in competition. ${ }^{5}$

In economics, Werner Sinn writes, with the same thrust, that "nothing could be more misleading than the usual conclusion by analogy" between State and market. ${ }^{6}$ The fundamental economic objection is that competition between legal orders constitutes a duplication of market failure. If market failure is regarded as a potential justification for State intervention, the State must act as a stopgap. But if the State is itself "marketed", this is no longer possible. The critique is that re-introducing the market by the back door of competition between legal orders would make the failures that caused the State to intervene in the first place resurface at the higher level of intergovernmental competition. ${ }^{7}$

However, there seems to be no consensus among economists about the usefulness of the theory of market failure to justify the performance of certain functions by the State. Contrary to the beliefs held in the traditional field of public finance, proponents of public choice rather opine that State intervention in the market process is normally pernicious. On the whole, the question of the applicability of the market mode to the State and its legal order appears to be still unresolved in economic theory.

From the point of view of constitutional law (that is the body of fundamental legal norms governing a polity which are often but not inevitably codified in a specific legal document), we might say simplistically that "market" and "State" represent the two basic and partly antagonist organising principles of any human society, namely freedom and equality. The market and its mode of competition stand for freedom and individuality, whereas the State and its law, in contrast, stand for the general public interest and thus rather for equality. Further dichotomies spring to one's mind: coercion by the State versus voluntariness in the market; unilateral-hierarchical modes of government versus contractually-horizontal action in the market; public interest pursued by the State versus self-interest pursued by market participants; the principle of limited government versus profit maximisation in the market. Above all, the State is obliged to respect the rule of law, while the providers in the market are basically free to act at whim. These dichotomies suggest that the functional logic of a State is fundamentally different from that of the market. That logic might be opposed to an application of the concept of competition to the State. Nevertheless, the rankings and PR measures mentioned in the introduction show that States (or rather the governing elites) do at least believe they are in competition.

\section{Problématique and Basic Concepts}

The divergence between the practice of competition among States and the theory of irreconcilable paradigms (States as opposed to markets) provokes two questions. The first is an analytical one: does the reconceptualisation of the sovereign activity of law-making and of law reform as a competitive bid yield anything for a legal analysis? The second question is a normative one: should the competitive paradigm serve as a normative guideline for legislators?

On the analytical plane, we must first briefly recapitulate the meaning of competition. Here a distinction should be drawn between competition in a broad and in a narrow sense. An ordinary dictionary defines competition (in a broad sense) as "the act or process of trying to get or win something (such as a prize or a higher level of success) that someone else is also trying to get or win". ${ }^{8}$ Put differently, when two or more players compete to obtain a

\footnotetext{
${ }^{3}$ Law Society of England and Wales. (Ed.). England and Wales: The Jurisdiction of Choice. www. lawsociety.org.uk.

${ }^{4}$ Seminally Kieninger, E.-M. (2002). Wettbewerb der Privatrechtsordnungen im Europäischen Binnenmarkt. Tübingen, Germany: Mohr Siebeck.

${ }^{5}$ Kirchhof P. (2005). Freiheitlicher Wettbewerb und staatliche Autonomie - Solidarität. ORDO, 56, $39-45$ (40); Grzeszick B. (2003). Hoheitskonzept - Wettbewerbskonzept. In J. Isensee, \& P. Kirchhof (Eds.), Handbuch des Staatsrechts (Vol. IV, 3rd ed., pp. 367 et seq.). Heidelberg, Germany: C.F. Müller.

${ }^{6}$ Sinn, H. W. (2003). The New Systems Competition (p. 7), Oxford, England: Wiley.

${ }^{7}$ Sinn, H. W. Competition (note 6), p. 6.

${ }^{8}$ Competition. In Merriam-Webster Online. Retrieved November 14, 2013, from http://m-w.com/dictionary/competition.
} 
good, there is competition in a broad sense. The prime example is sport, in which a number of athletes compete for a title. The rivalry between political units for political and economic supremacy has - starting with Athens and Sparta - always been described as such competition in the broad sense, also comprising competition between the respective legal order (e.g. democracy versus monarchy). ${ }^{9}$

Contemporary economic analysis does not relate to such "bipolar" relationships, but takes the market as its basis. Competition is viewed as an interaction structure of the market. The market, in turn, is the point where supply and demand meet. Here the relationship is "tripolar", because customers come into play, to whose demand a provider reacts. In the terminology of economics, competition within a market consists in a parallel process (between the competing suppliers) and an exchange process (between the suppliers and the demanders). ${ }^{10}$ This is a fundamentally different interaction structure from the "bipolar" one. This sort of competition (on a market) is, according to general usage of the word, "the effort of two or more parties acting independently to secure the business of a third party by offering the most favorable terms." "11

From the competition perspective, the merchandise (or product) supplied is - in the context that this paper examines - the entire legal order. Similar terms used for this phenomenon, the competition of legal orders, or for closely related phenomena are: "competition of institutions, ${ }^{12}$ "systems competition", 13 "jurisdictional competition", 14 and "regulatory competition." In this paper, I will use those terms interchangeably.

Moving to the second level, the normative analysis, we must ask what the yardsticks for the evaluation of the ("tripolar") market competition about the product (the law viz. an entire legal order) are. From a purely economic perspective, the yardstick against which to evaluate (potential) benefits of regulatory competition is solely its capacity to realise the generally acknowledged benefits of competition. These are: better products, a greater choice, and lower prices. But when is the product (the legal order) better? It is better - within the competition paradigm - not when it fulfils predetermined independent criteria, but when it satisfies the customers' individual preferences, which in turn relate to goods which are shaped by the law, such as transport infrastructure, schools, work, environmental quality, or the tax burden. From that perspective, competition of legal orders is a good thing to the extent that it causes States to develop new law and thus improves the product law, and when it leaves persons subject to the laws a choice (of law).

From a legal perspective, however, the merits (or drawbacks) of regulatory competition must be (also) assessed against the yardstick of constitutional principles. Put differently, the lawyerly examination needs to assess and evaluate the benefits of that competition process with a view at legal criteria which do not necessarily coincide with personal preferences of individuals, such as capacity of the competition process to secure respect of legal (and even constitutional) principles, namely security, freedom, and equality. It is difficult to assess or even measure the capacity of laws (or an entire legal system) to promote and respect those legal principles. In the recent years, indicators have been developed to this end. ${ }^{15}$ Qualitative and quantitative indicators (structural indicators, procedural indicators, and outcome indicators) are being used both to guide the formulation of policies and laws, and to measure the quality and the implementation of law with the methods of sociological research. Such indicators may be used to assess the state of implementation and realisation of human rights guarantees including social rights (health, education, and so on) and political rights (right to life, freedom from torture, and so on). But it is important to keep in mind that indicators, while complementing assessments with a strong qualitative dimension (e.g. findings of human rights violations), may not replace those. ${ }^{16}$

\footnotetext{
${ }^{9}$ Cf Aristotle. (2000). Politics, Book III (1279b), Oxford, England: Clarendon Press.

${ }^{10}$ See for these terms Hopmann, E. (1967). Wettbewerb als Norm der Wettbewerbspolitik. ORDO, 18,77 et seq. (88 et seq.).

11 “Competition". In Merriam-Webster Online. Retrieved November 14, 2013, from http://m-w.com/dictionary/competition.

${ }^{12}$ See e.g. Bergh, A., \& Höijer, R. (Eds.) (2008). Institutional Competition, Cheltenham, England: Edward Elgar Publishing.

${ }^{13}$ See e.g. Becker U., \& Schön, W. (Eds.) (2005). Steuer- und Sozialstaat im europäischen Systemwettbewerb, Tübingen, Germany: Mohr Siebeck; Breton, A., (1996). Competitive Governments, Cambridge, England: Cambridge University Press.

${ }^{14}$ See Bratton, W. W., \& McCahery, J. A. (1997). The New Economics of Jurisdictional Competition: Devolutionary Federalism in a Second-Best World. Georgetown Law Journal, 86, 201-278.

${ }^{15}$ Candler, J., Holder, H., Hosali, S., Payne, A. M., Tsang, T., Vizard, P. (2011). Human Rights Measurement Framework: Prototype Panels, Indicator Set and Evidence Base. Equality and Human Rights Commission (Scotland); United Nations, Office of the Human Rights Commissioner (UNHCR) (2012). Human Rights Indicators: A Guide to Measurement and Implementation. See in scholarship: Landmann, T. \& Carvalho, E. (2010). Measuring Human Rights. London, England: Routledge; Langford, M., \& Fikuda-Parr, S. (2011). The Turn to Metrics. Nordic Journal of Human Rights, 30, 222-236; Davis, K. E., Fisher, A., Kingsbury, B. Merry, S. E. (Eds.) (2012). Governance by Indicators: Global Power through Quantification and Rankings. Oxford, England: Oxford University Press.

${ }^{16}$ UNHCR (note 15), p. 21.
} 
The paper will proceed, first, with the positive analysis (section 4), and then move to the normative analysis of the competition between legal orders (section 5).

\section{Positive Analysis of the Competition Paradigm}

What is the analytical added value of applying the competition paradigm to legal orders? The answer depends first of all on the rigour of the analogy, which will be examined in what follows.

\subsection{The Product and its Providers}

The legal order as the product: the object of the supposed competition would be the legal order (or legal system; used synonymously in this paper). Law is conceived as the product or merchandise. Just like a raw material, law seems to be a pre-product for the actual production of goods. ${ }^{17}$ This raw material is offered on the law-market. ${ }^{18}$ (The marketability of the law cannot a priori be ruled out on the basis that the framework of the market for its part must be constituted by (an additional set of) legal norms.) One characteristic of an entire "legal order" as one product is its high degree of bundling. This package can barely be unbundled by its users. Another feature is that although the billions of citizens-customers have billions of different preferences, they only have an extremely small choice among only 192 national legal orders.

Globalisation brings to an end the State monopoly of law: competition presupposes a plurality of providers or suppliers. In contrast, constitutional theory has traditionally assumed that the State is a monopolist. The State has been regarded as the sole ultimate source of all law. From a traditional constitutional law-perspective, foreign law or privately-generated law cannot apply within the national territory of a State unless the State authorises such an application, either explicitly or implicitly.

However, globalisation and global governance have called into question the traditional monopoly position of the State as the provider of law. Natural and moral persons subject to State-made law have at least some limited physical exit options. Also, choice-of-law-options seem to be extending. Finally, intergovernmental and non-governmental actors play an increasingly independent role in law-making. Overall, globalisation has created a new situation which has been called a "new systems competition". ${ }^{19}$

State and non-State providers: in this "new" competition, the Nation States, more specifically the legislative bodies and the courts, are the providers of the "legal order" as a merchandise. Further providers are the constituent units of federal States, regional and local authorities such as municipalities, and international or supranational organisations. National legal systems are in competition not only with one another, but also with "supra"- and "infra"-national systems. A vertical or multi-level competition notably takes place between EU-law and the domestic law of the Member State, but of course only in fields where the law-making competence does not remain exclusively with the Member States or has not been exclusively conferred on the EU. Multi-level competition within the EU thus only takes place in areas of shared competences in terms of Art. 2 sec. 2, 5 and Art. 4-6 TFEU.

To a limited extent, social players are providers of (sub-)legal systems, too. Throughout history, those systems were often in competition with State-made law. One example is the medieval rivalry between ecclesiastical and secular law, which was presumably a decisive driving force for the development of modern legal orders in Europe. $^{20}$ Today, non-State actors produce a diverse range of standards, extending from indigenous law ${ }^{21}$ through the lex mercatoria to corporate codes of conduct. Legal pluralism perceives these social groups as original producers of law. ${ }^{22}$ The competition paradigm underscores the legal pluralist view: if law is a product, it

\footnotetext{
${ }^{17}$ Heine, K. (2003). Regulierungswettbewerb im Gesellschaftsrecht (p. 100), Berlin, Germany: Duncker \& Humblot. On law as a product see also Eidenmüller, H. (2009). Recht als Produkt. JuristenZeitung (JZ) 64, 641-652.

${ }^{18}$ O'Hara, E., \& Ribstein, L. E. (2009). The Law Market, Oxford, England: Oxford University Press.

19 Sinn. Competition (note 6).

${ }^{20}$ Berman, H. (1998). The Western Legal Tradition: The Interaction of Revolutionary Innovation and Evolutionary Growth. In P. Bernholz, M. E. Streit, R. Vaubel (Eds.), Political Competition, Innovation, and Growth: A Historical Analysis (pp. 35 et seq. (pp. 38-9)). Berlin, Germany: Springer Verlag on "late eleventh century with the church's establishment of an external forum, a hierarchy of ecclesiastical courts with exclusive jurisdiction in some matters ... The pluralism of Western law was a source of legal sophistication and of legal growth. It was also a source of freedom."

${ }^{21}$ See on the right to promote, develop and maintain indigenous "juridical systems" Art. 34 of the United Nations Declaration on the Rights of Indigenous Peoples of 13 September 2007 (UN-Doc. A/61/L. 67).

22 Teubner, G. (1997). "Global Bukowina": Legal Pluralism in the World Society. In G. Teubner (Ed.), Global Law Without a State (pp. 3-28). Farnham, England: Ashgate; De Sousa Santos, B. (2002). Toward a New Legal Common Sense (2nd ed.). Cambridge, England: Cambridge University Press.
} 
can, like any other merchandise, be manufactured and offered by private individuals, and there would be no reason to have a State monopoly on the production of law. ${ }^{23}$ It would be consistent with the competition paradigm if the State created incentives for private actors to produce the "merchandise" law by granting them copyright protection or by providing other legal schemes which might facilitate non-State standard setting.

\subsection{Law-Customers and Their Choice of Law}

In the legal orders market, those who are subject to the law are the "law-customers", the "law clients", or those who "demand" law, in their capacity as voters, taxpayers, owners of financial or real capital, and consumers. What is known as "regulatory arbitrage" by those customers, that is, the choice of the legal order they prefer, can take place in various modalities. The basic ones are "voice" and "exit", ${ }^{24}$ although further modalities exist as well.

\subsubsection{Direct Choice of Law: Some Examples}

In democracies, the "voice" is normally cast in political elections, while it can also be raised in citizens' protests and lobbying activity. Besides the democratic process, numerous other (much more direct) mechanisms allow the "law clients" to express their preferences for a specific law or legal order.

The usual mode of choosing law happens under conflict-of-law-provisions (private international law) which probably all national legal systems possess in form of codes or case-law. This type of choice of law is available in various transnational constellations (transnational contracts; transnational families; torts, etc.), and normally does not require the involved parties to change their physical location. The rules of private international law may not only leave a choice to the persons subject to the law but sometimes also to the law-applying authorities. For example, a judge may be asked, in a family case, to decide which law should govern the relationships of a child to its parents (custody etc.) if those have different nationalities and/or different domiciles. Some systems of private international law will allow the judge to compare the relevant rules of the various involved States and choose to apply those which are in the best interest of the child. However, in this constellation, it is not the actual "consumer" (the child itself) which chooses, and the judge's choice does not exert pressure on the law-maker to modify its legal order.

The choice can also be realised in the field of legal procedure, for example through arbitration clauses. The choice of a specific tribunal or of any other dispute settlement body often determines which law will be applied to the merits of a dispute. Here the market analogy is present in the concept of "forum-shopping". ${ }^{25}$

Another mode of choosing law is the purchase of products that satisfy the standards of a foreign legal system. If a purchaser buys French cheese made from unpasteurised milk, he/she decides in favour of French production standards and accepts the danger to his/her own health. In any case, the consumer opts for this part of the legal order - the hygiene regulations - with his/her purse. ${ }^{26}$

\subsubsection{Indirect Choice of Law through "Exit"}

In principle, people can also choose a legal order through "exit." They may emigrate if they are dissatisfied with the legal order they live under. ${ }^{27}$ Already the medieval principle that "city air... makes one free after a year and a day" which referred to the choice of law through physical displacement, by emigration from the countryside into a European medieval city. Another example is the "beneficium emigrandi" enshrined in the Peace of Augsburg of 1555 , which gave individuals a right to emigrate to a different territory in which their religious creed was accepted by the ruler. Today, political refugees are law-consumers looking for a free and fair legal system. Migration for economic reasons can also be interpreted as indirect "voting with the feet" against the emigrants' poor home country's legal orders, because the underdevelopment which migrants seek to escape has its roots, inter alia, in the legal system itself, for example in deficient protection of property rights or insufficient laws against corruption. The same mechanism, namely "voting with the feet" against deteriorating living

\footnotetext{
${ }^{23}$ Bachmann, G. (2006). Private Ordnung: Grundlagen ziviler Regelsetzung (pp. 50 and 52). Tübingen, Germany: Mohr Siebeck.

${ }^{24}$ Hirschman, A. O. (1970). Exit, Voice and Loyalty: Responses to Decline in Firms, Organizations and States. Cambridge, MA: Harvard University Press.

${ }^{25}$ Cf. Thompson Denning, A. known as Lord Denning (1972). The Atlantic Star. All English Law Reports 3, 705 et seq. (709): "This right to come here is not confined to Englishmen. It extends to any friendly foreigner. ... You may call this 'forum shopping' if you please, but if the forum is England, it is a good place to shop, both for the quality of the goods and the speed of service."

${ }^{26}$ Muir-Watt, H. (2004). Aspects économiques du droit international privé. Recueil des cours de l'Académie de la Haye, 307, 25-383 (54).

The buyer exercises - as is said in the jargon - his/her consumer sovereignty and casts his/her "consumer-vote".

${ }^{27}$ See below on the human rights-quality of the right to emigrate note 87.
} 
conditions which partly result from municipal laws (in the area of education, taxes, infrastructure) may be one explanatory factor for the phenomenon of shrinking cities, notably in the developed world. ${ }^{28}$

However, the "exit"-mode of choosing law or an entire legal system is not equally available to all consumers of the law. Only financial capital enjoys full mobility in fact, because its mobility costs are extremely low. In contrast, due to high mobility costs (such as human and cultural losses), natural persons remain rather immobile, except at the top and bottom ends of the income scale. Natural persons tend to be more mobile only across jurisdictions which extend over a very small surface area. It is no coincidence that Charles Tiebout established his famous competition model for U.S. municipalities (not with a view to the entire Nation State), ${ }^{29}$ and that legal competition among the Swiss Cantons (which are very small) is fierce. ${ }^{30}$

Besides individual emigration, the so-to-speak collective emigration of citizens along with their territory through secession, can in the competition paradigm be reconstructed as a choice of law, made by that collective. ${ }^{31}$ Some economists do in fact interpret a group's threat with secession as a permissible modality of choice that may put legislators under a pressure to adapt the law of the territory. ${ }^{32}$ A scholarly proposal to create functional, overlapping jurisdictions, a form of administration unions, relies on the same logic, namely to allow for consumer-adapted legal sub-systems for defined issue areas, detached to a certain extent from territory. ${ }^{33}$ However, under current public international law, secession is basically prohibited. This means that the secession of a territory from an existing State - which would be consistent in the competition paradigm - is for legal reasons unavailable as a modality of choice of law.

A different mode of choosing law is to change one's nationality. This might be conceptualised as a kind of "exit", too, because it leads to the applicability of an entire new legal order by virtue of the naturalising State's jurisdiction over its citizens. For companies within the meaning of Article $54 \mathrm{sec} .2 \mathrm{TFEU}$, it is easy to adopt a new organisational law or new articles of association through a company's re-incorporation under a new legal order. When this is done in a constellation in which the applicable choice-of-law-rules follow the incorporation theory (as opposed to the seat theory), a complete exchange of the constitutive law of the company is possible without even having to relocate physically the main administrative seat of the company. ${ }^{34}$

The situation is different for natural persons. With the idea of competition in mind, economists have proposed tradable citizenships that would be able to be resold when switching to a different jurisdiction. ${ }^{35}$ This proposal appears difficult to reconcile with the ideational and permanent nature of nationality. Yet, it is precisely this type of choice of legal order that is currently popular in Eastern Europe. In particular, the Russian Federation has generously bestowed Russian citizenship on residents of neighbouring States, without the latter having to take up residence in Russia. Within the two separatist territories of Georgia, in South Ossetia and Abkhazia, the inhabitants scramble to obtain the Russian citizenship which entitles them, inter alia, to Russian social-welfare benefits and which enables them to participate in the EU Visa facilitation programme. ${ }^{36}$

A yet different type of "exit" is the withdrawal of a Member State from an international organisation. From the competition perspective, such a withdrawal amounts to a choice of law, too, namely opting against the

\footnotetext{
${ }^{28}$ See UN Habitat (Ed.) State of the World's Cities 2008/2009 (pp. 40-47). New York, NY: UN; Richardson, H. W. \& Nam C. W. (Eds.). (2013). Shrinking Cities: A Global Perspective. London, England: Routledge; Pallagst, K. M., Wiechmann T., Martinez-Fernandez, C. (Eds.). (2013). Shrinking Cities: International Perspectives and Policy Implications. London, England: Routledge.

29 Tiebout, C. M. (1956). A Pure Theory of Local Expenditures. The Journal of Political Economy, 64, 416-424.

${ }^{30}$ See the empirical research by Feld, L. (2006). Regulatory Competition and Federalism in Switzerland: Diffusion by Horizontal and Vertical Interaction. In CREMA (Center for Research in Economics, Management and the Arts) Working Paper No. $2006-22$. http://www.crema-research.ch/papers/2006-22.pdf.

${ }^{31}$ See on ideas of entrepreneurs in Silicon Valley to secede from the USA in order to escape regulation Giridharadas, A. (2013, October 28). Silicon Valley Roused by Secession Calls. New York Times.

${ }^{32}$ See Buchanan J., \& Faith, R. (1987). Secession and the Limits of Taxation: Toward a Theory of Internal Exit. American Economic Review, 77, 1023-31.

${ }^{33}$ See in support of this Frey, B., \& Eichenberger, R. (1999). The New Democratic Federalism for Europe: Functional Overlapping and Competing Jurisdictions. Cheltenham, England: Edward Elgar Publishing.

${ }^{34}$ ECJ, case C-212/97, Centros Ltd v. Erhvervs-og Selkabsstyrelsen, ECR 1999, I-1459; case C-208/00, Überseering, ECR 2002, I-9919; case C-167/01, Inspire Art, ECR 2003, I-10155; case C-210/06, Cartesio Oktató és Szolgáltató bt, ECR 2008 I-3468. Cf. Advocate General A. La Pergola in Centros, para. 20 at note 49 referring to C. D. Ehlermann on "competition among rules".

35 Tullock, G. (1997). Trading Citizenship. Kyklos 50, 251-252.

${ }^{36}$ See Independent International Fact-Finding Commission. (2009). Report of September 2009, “Passportisation” (Vol. II, Chapter 3, Part 3), 147 et seq. www.ceiig.ch.
} 
organisation's legal regime. Such a withdrawal from international organisations is legal (see for the EU Art. 50 TEU), and hence constitutes a real choice-of-law-modality.

\subsection{The Lack of a Competition Cycle}

The direct or indirect choice of a legal system that can be exercised by the law consumers in the modalities described above leads to actual competition only if these choices exert pressure on the law-providers to adapt, so that the latter will indeed reform the legal order so as to satisfy the preferences expressed by the consumers. The competition paradigm fits only if it can be reasonably said that law consumers pay a "price" for the legal order they desire, and that the law-provider makes profit when it responds to legal consumers' wishes. Only then, a real competition cycle exists.

In this section, I shall discuss the incentives created for the providers of law through the "consumers" election of a political party that will then dominate parliament, and through the consumers' threat with emigration (i.e. choice through "voice" and "exit"). I will not dwell on the incentives created for law-providers through the other modalities of choice mentioned above, i.e. through the purchase of foreign goods, the threat with secession, or the acquisition of a foreign nationality. The pressure to adapt the law exercised by these expressions of preference is rather weak, anyway.

Any competition cycle is completely lacking in the ordinary process of reception of foreign legal institutions and systems, for example the reception of Western constitutional institutions in Central and Eastern democracies in the 1990s. Although such reception processes are often described as "yardstick competition", ${ }^{37}$ competition in the sense described above does not exist. The reason is that the reception processes are not decisively set in motion by the demand of the citizen-"customers". Law-makers adopt foreign law and institutions primarily for reasons which are not connected with the "customers". And on the side of the "law-exporter", the export of the domestic institutions does not lead to its own legal system being reformed in response to "customer" requests. Thus, the cycle that is typical of "tripolar" market competition, a cycle in the sense that the providers react to the customers' preferences, is not present in the context of legal reception. Labelling legal reception as yardstick competition is therefore misleading.

More fundamental problems attach to the competition paradigm, when applied to the legal order: there is no contract and no price. First, no enforceable contract may be concluded on the product law. The contrat social is not justiciable. Second, even proponents of the idea of competition between legal orders do not take the view that this means that citizens should pay money in exchange for legal services, for example, for obtaining a building permit. Rather, the "payment" of a "price" for the law is considered to be present in three different items: in the voter's vote, in his continued residence in the State, or in his payment of taxes. All three behaviours can only with difficulties be reconstructed as "paying a price" for a good.

This is most obvious with taxes. From a legal perspective, taxes are by definition not the remuneration for specific services provided in return by the State. The level of tax that is paid in a given State is not determined by the State-services provided to individuals, last but not least because these are virtually impossible to measure. The tax rate is therefore calculated on the basis and justified with a view to the taxpayers' capacity to pay. The State's revenue from taxes and fees (for example, the company registration fee in the U.S. State of Delaware ${ }^{38}$ ), is then - from an orthodox tax law perspective - not used to satisfy specific wishes of taxpayers, notably not preferences concerning the shape of the legal order, but simply as a general governance resource of the State.

In the end, the so-called "competition" of laws of legal systems is just one element in a purely economic competition among States. "Competing" law-makers strive to generate economic wealth in their State, either because they idealistically seek to serve the public interest, and/or because they seek to preserve their position of political power. A flourishing economy is normally "rewarded" by voters. However, the cycle postulated in the competition paradigm - from the customer's wish to product innovation and back to the customer - that is, the competition cycle, hardly runs really smoothly in relation to legal orders. ${ }^{39}$ On the provider's side, the law-makers would need to have precise data on the mobility and the other choice-of-law-decisions made by their customers, interpret them and make appropriate offers to improve their legal product. But in reality, the law-providers - the political parties - can hardly attribute the causes of losing voters to specific aspects of the law in force. This means that political elections do not exercise pressure on the law-provider to furnish a

\footnotetext{
${ }^{37}$ For the term "yardstick-competition" see Shleifer, A. (1985). A Theory of Yardstick Competition. The Rand Journal of Economics, 16, 319 et seq.

${ }^{38}$ A considerable part of Delaware's budget is financed by the revenues of this franchise tax (30 Del. C, Section 1902(b)(6)).

${ }^{39}$ See on this Kieninger. Wettbewerb (note 4), pp. 51-65.
} 
modified product, new laws. The same lack of pressure is absent with regard to "choices" through exit. Migrants exert hardly any pressure on law-furnishers to adapt their product, either on the deficient legal system that they are fleeing or on the destination State, which often would prefer to get rid of them again. Legal reforms are therefore hardly ever triggered clearly by choice-of-law-decisions made by natural persons, be it through "voice" or through "exit". The only constellation in which a cycle might be said to exist is in the tax-law competition between jurisdictions. Industries can plausibly threaten to relocate abroad and thereby exercise pressure on tax-law-makers, which will then adapt their product (tax law) in order to keep or attract investors within their jurisdiction.

\subsection{Conclusion: Reconstructing Legal Evolution as a Competition about the Product "Law"}

So does it have an analytical added-value to consider law as a product, the State as its producer, and the citizen as the customer? As explained above, we do not need the market paradigm to understand better the mechanism of legal reception. But with regard to other constellations, we have seen that a host of differing law selection-mechanisms are at work in the "tripolar" relationship between the consumers of law and the multiple competing legal orders. These mechanisms rarely concern entire legal orders, but rather specific legal sub-systems. For example, the option of choosing law under conflict-of-law-provisions is not available in public law (only in private law, such as contracts, torts, and family law). Next, tax-law competition ${ }^{40}$ is most of all a form of territorial competition. In contrast, competition in contract law is a largely de-territorialised form of competition. Competition in company $\operatorname{law}^{41}$ is both: territorial and de-territorialised. Finally, the decision to purchase a foreign good concerns only product standards (and these only marginally), so that it appears artificial to describe that behaviour as a choice of law.

Overall, the translation from the sphere of the "sovereign" to the sphere of "competition" is a useful heuristic. Indeed, the act of translation sharpens the eye for differences, that is for the specific characteristics of the State and for what distinguishes it from the market. The reconstruction of the legal reform as "competition" on a "law market" opens up a new perspective, which can be fruitful, but only partially.

Most of all, no legal policy recommendation can be derived directly from this diagnosis. Such recommendations depend on the normative assessment of the phenomena which follow in the next section.

\section{Normative Assessment of Competition between Legal Orders}

The description and interpretation of the evolution of legal orders as a kind of competition allows to identify both negative and positive effects of the phenomena. In a normative perspective, I will confine myself to assessing the effects of the legal systems competition on five legal principles (or "goods" - in the competition paradigm): freedom, equality, democracy, the social principle and the public interest.

\subsection{Ensuring Freedom through Competition between Legal Orders}

The most fundamental justification for competition between legal orders is that this competition enhances freedom. Already Max Weber maintained that the liberation and formation of a national bourgeoisie was a result of competition between modern States for "freely moving" capital. ${ }^{42}$ Today, public-choice scholars in particular emphasise that the threat of emigration (of natural and moral persons) compels States to remain "lean" with their legal order, which, it is claimed, enhances the citizens' freedom.

However, it does not follow from this potentially freedom-ensuring function of inter-State competition that the conventional, non-fiscal instruments for controlling and restraining the power of the State have become obsolete. The classic juridical mechanisms for limiting political power remain relevant, because competition between States and their legal systems does not suffice to eliminate the potentials for abuses of governmental power.

\footnotetext{
${ }^{40}$ See for legal literature on tax competition Avi-Yonah, R. S. (2000). Globalisation, Tax Competition and the Fiscal Crisis of the Welfare State. Harvard Law Review, 113, 1573 et seq.; Schön, W. (2002-3). Steuerwettbewerb in Europa. Archiv des schweizerischen Abgabenrechts 71, 337-383; Schmehl, A. (2009). Nationales Steuerrecht im internationalen Steuerwettbewerb. In W. Schön, \& K. E. M. Beck (Eds.), Zukunftsfragen des deutschen Steuerrechts, MPI Studies on Intellectual Property, Competition and Tax Law, (pp. 99-123). Berlin, Heidelberg, Germany: Springer Verlag. From economics Gerken, L., Märkt, J., Schick, G. (2000). Internationaler Steuerwettbewerb. Tübingen, Germany: Mohr Siebeck; Höijer, R., Tax Competition and Tax Cartels. In Bergh \& Höijer (note 12), 129-154.

${ }^{41}$ See Romano, R. (1993). The Genius of American Corporate Law. Washington DC: Aei Press; Heine, K. (2003). Regulierungswettbewerb im Gesellschaftsrecht. Berlin, Germany: Duncker \& Humblot; Teichmann, C. (2006). Binnenmarktkonformes Gesellschaftsrecht. Berlin, Germany: de Gruyter Recht.

${ }^{42}$ Weber, M. (1923). Wirtschaftsgeschichte: Abriss der universalen Sozial- und Wirtschaftsgeschichte (pp. 288-289). München, Leipzig, Germany: Duncker \& Humblot.
} 
Competition between their legal systems thus by no means exempts State authorities from their obligation to abide by the law and the constitution. ${ }^{43}$ On the other hand, it does not follow that only conventional juridical power-limitation mechanisms should be allowed. Competition between legal systems may be a complementary strategy to ensure the people's freedom as long as the rule of law governs.

\subsection{Competition between Legal Orders and the Principle of Equality}

Secondly, competition between legal orders challenges traditional concepts of equal protection. The competitive situation might prompt the legislator, in particular the tax legislator, to violate the principle of equal treatment in order to preserve or create jobs and sources of tax revenue. ${ }^{44}$

However, the principle of equality does not demand schematically identical treatment. The common feature of all domestic and international equal protection regimes is that distinctions which are proportionate to realising legitimate aims are permissible. The question then is whether, under what conditions and to what extent novel legislative objectives, such as the need to attract and keep foreign capital in the country, are to be recognised as legitimate grounds for distinctions made by the law, for example in taxation. Particularly in tax law, one permissible ground for a differential treatment of taxpayers might be their proneness to migrate. Along these lines, natural or moral persons likely to leave the country might be permissibly subjected to lower taxation. This would constitute a departure from the traditional scheme within a "closed state", namely that taxpayers who are equally wealthy must be subject to equal taxes. ${ }^{45}$ Under German constitutional law, to give one example, the normative justification for such distinctions is the constitutional principle of open statehood. ${ }^{46}$

\subsection{Competition between Legal Orders and Democracy}

One main argument of proponents of competition between legal orders is that such competition fosters democracy. From a public-choice perspective, competition between legal systems rectifies and counteracts the structural bias of the domestic democratic process. That structural bias arises from the relative lack of information on the side of the legislator and the disproportionate influence of interest-groups on the legislative process. ${ }^{47}$ The structural bias leads to suboptimal laws, i.e. to laws which disproportionately respond to the interests of influential groups.

But this classic justification of a competition between legal orders - namely that it enhances democracy within the Nation State - is flawed on several grounds. First, there is the risk that legal competition, rather than breaking up the political process, may again give preference to special interests. Those players who can "vote with their feet" more than others are exactly those who are the better lobbyists anyway. The more credible an actor's (for example an industry's) threat of emigration is, the louder is its voice in the political process, too. ${ }^{48}$ This applies to capital, in particular financial capital, which is much more mobile than labour forces and whose voice as a result becomes more influential. ${ }^{49}$ Seen in such terms, competition between legal systems greatly accentuates the deficiencies of the democratic process rather than compensating for them.

Secondly, competition between legal systems is inseparably linked to political competition, because the law-maker's reactions will necessarily take place as part of a political process. The deficits of the political process thus impinge upon competition between legal systems. ${ }^{50}$ Therefore, the compensation argument is to some extent circular.

As a result, legal-systems competition cannot compensate for a lack of democracy in political competition and therefore does not per se have a democracy-strengthening effect. On the contrary, it even risks to damage the

${ }^{43}$ Gerken, L. (1999). Der Wettbewerb der Staaten (p. 56). Tübingen, Germany: Mohr Siebeck.

${ }^{44}$ See Swiss Federal Tribunal (Schweizerisches Bundesgericht) BGE 133 I 206, E. 10.2. (2007) on the degressive income tax of the Canton Obwalden.

45 German Constitutional Court (Bundesverfassungsgericht), BVerfGE 116, 164 (192, paras 98-99 and 111) (2006) Standortsicherungsgesetz, Tarifbegrenzung bei gewerblichen Einkünften; see also BVerfGE 110, 274 (299, paras 74 et seq.) (2004) Ökosteuer.

${ }^{46}$ Di Fabio, U. (2007). Steuern und Gerechtigkeit, JZ, 62, 749-755 (755).

${ }^{47}$ Olson, M. (2003). (Ed.). The Logic of Collective Action: Public Goods and the Theory of Groups (21st. ed.). Cambridge, MA: Harvard University Press.

${ }^{48}$ German Monopolies Commission (Monopolkommission) (2000). Special Report 27 on Systems Competition (Sondergutachten 27 Systemwettbewerb), 17.

${ }^{49}$ Sinn. Competition (note 6), p. 60: "Capital, except possibly for corporate capital trapped by divided taxes, will be the big winner of systems competition."

${ }^{50}$ Monopolkommission (note 48), 19. 
principle of democracy because the "customers" of the law do not enjoy formally equal standing in the process of competition (as opposed to the formal equality in the political process guaranteed by the principle of "one man - one vote"). The "consumers" de-facto-inequality of influence poses a democratic problem because the individual choices of law made by some players almost always have an impact on outsiders who will be subjected to the laws which result from the "competition". ${ }^{51}$ Overall, the unequal positions of the law-consumers is acceptable in a democratic State only as long as democratic and strictly formally egalitarian procedures still formally govern the law-making process. Competition between legal systems that is governed by the principle of unequal market power is not an alternative process to democratic, general and equal elections and ballots.

Far from viewing competition as an asset to democracy, some critics of the competition paradigm even argue that competition between legal systems damages democracy because it undermines the power of parliament. However, the root cause is not the competition in itself but rather the conditions of globalisation which have opened the possibilities for the "clients" to evade national laws. It is the numerous direct and indirect choice-of-law-options available to natural and moral persons that cause a loss of control of the State (and of its parliament). Global interdependence and the mobility of products and capital have reduced manoeuvring space for Nation States. These phenomena have in themselves weakened democratic self-determination on a national level. This fact is independent of whether the said phenomena are conceptualised as systems-competition or not.

The democratic law-maker remains free to set its political priorities. Nothing compels national parliaments to strive to attain a top rank in the legal systems competition. However, any parliament that refuses to participate in the systems-competition simply exacerbates the problem. Standing on the side line would weaken the Nation State's democracy more in its output dimension than entering the competition would. A strengthening of democratic policy-making can be achieved mainly by accepting competition as a political challenge and by embedding it legally.

\subsection{Competition between Legal Orders and the Social Principle}

Competition between legal orders may indirectly generate wealth, in that the "products" in this competition - the legal rules - develop into better and more demand-oriented conditions for economic and thus wealth-promoting activities. On the other hand, competition stands in an obvious tension with the principles of the social state and of solidarity. ${ }^{52}$

\subsubsection{Neglect of Powerless Actors and Lack of Distributive Justice}

In a market, the preferences of the more powerful groups (those who can pay a higher price) are better served than those of the weaker groups. Entities or actors who do not have any voice to express their preferences and to pay, such as the environment, animals or future generations, are not taken into consideration at all in a pure market mechanism.

In addition, competition does not allow for any, or only a small degree of, social redistribution. This is particularly obvious in tax competition. In order to remove the incentive for wealthy taxpayers to migrate to low-tax jurisdictions, States are inclined to cut taxes, as a result of which the finances available for redistribution shrink. The policy-shift from direct to indirect taxation - which has taken place in response to the risk of emigration - also reduces options for redistribution. ${ }^{53}$

This issue can be framed in terms of justice. The "invisible hand" may guide individuals to unintentionally promote the public interest by pursuing their own self-interest. ${ }^{54}$ But this market mechanism creates only

\footnotetext{
${ }^{51}$ See along this line Bachmann, G. (2012). Vertikaler Regulierungswettbewerb im Euopäischen Gesellschaftsrecht. In B. Erle et al. (Eds.), Festschrift für Peter Hommelhoff zum 70. Geburtstag (pp. 21-44). Köln, Germany: Verlag Dr. Otto Schmidt.

${ }^{52}$ See for the social principle on the international plane the International Covenant on Economic, Social and Cultural Rights; on the national plane Art. 20 sec. 1 German Constitution (Basic Law, Grundgesetz (GG)); Art. 41 Swiss Federal Constitution, Bundesverfassung (BV). See for the EU Art. 3 sec. 3 TEU (Lisbon) and Art. 151 et seq. TFEU.

${ }^{53}$ See also text with note 60 .

54 "[E]very individual ... generally, indeed, neither intends to promote the public interest, nor knows how much he is promoting it. ... [H]e intends only his own gain, and he is in this, ... led by an invisible hand to promote an end which was no part of his intention. Nor is it always the worse for the society that it was not part of his intention. By pursuing his own interest he frequently promotes that of the society more effectually than when he really intends to promote it." Smith, A. (orig. London 1776). An Inquiry into the Nature and Causes of the Wealth of Nations (Book IV, chap. ii, para. 9, p. 456). Ed. (1979) by Campbell, R. H. et al. Oxford, England: Oxford University Press. "It is not from the benevolence of the butcher, the brewer, or the baker, that we expect our dinner, but from their regard to their own interest. We address ourselves, not to their humanity but to their self-love, and never talk to them of our own necessities but of their advantages." (ibid., Book I,
} 
compensatory justice through giving and taking - that is, justitia compensative, but not distributive justice (justitia distributive). ${ }^{55}$ This runs counter to the solidarity principle, which must be respected in a social welfare state.

\subsubsection{A Downward Spiral?}

The most serious threat to the social principle appears to lie in the much feared downward spiral. A gradual downward spiral caused by competition could affect, for example, environmental standards, social standards, and creditor protection in corporate law. A downward spiral in respect of taxes would in the long term erode the tax base and impoverish the State. The State would be driven, on the one hand, into debt, which would place an unfair burden on future generations, and on the other, compelled to underperform and reduce governmental tasks, including in the area of services of general interest. The long-term threat, according to the view of the competition critics, is self-destruction of the tax-financed State. ${ }^{56}$

However, the notorious race to the bottom ${ }^{57}$ is not generally recognised among economists, neither as a theoretical model nor as an empirical reality. ${ }^{58}$ Notably Richard Revesz has shown that race-to-the-bottom arguments are not covered by existing models of interjurisdictional competition. Even if there were a race to the bottom over environmental standards, regulation on a higher legal level (e.g. by federal law in a federal State or on the level of international law) would not be an adequate response. States concerned with attracting industry would reduce the standards in other areas. ${ }^{59}$

Moreover, the "race-to-the-bottom" hypothesis does not fit with regard to some fields of law, for instance competition law. In competition law, there is no clear-cut "minimum" and "maximum" level of protection, since its determination depends on the specific objective of the law which in turn is influenced by the underlying concept of competition and the model of competitive market economy. The objectives of contemporary national competition regimes are merely partly of an economic nature. Legal fields, such as competition law do not set any linear standards, and it is therefore not clear what the "bottom" is.

In other areas of law, in which a "bottom line" can be defined, the expected race to the bottom has in fact not always occurred. For example, in labour legislation, the transfer of production sites to low-wage-countries has not led to a lowering of health and safety standards in the industrialised countries. Those standards remain high thanks to technical progress. In contrast, some erosions are discernible in industrialised countries in relation to wages and protection against unfair dismissal. But these erosions are due to multiple factors and cannot necessarily be attributed to the competition with developing States.

Looking at the tax law of some States, no trend to reduce taxes is visible, neither have the tax revenues generally decreased. However, many countries shift away from direct taxation to indirect taxation, and from the taxation of mobile capital to the taxation of the more immobile production factor of labour and real estate. ${ }^{60}$ This can be interpreted as a reaction to the pressure of capital outflow.

A recent survey of global regulatory competition shows that the competition leads to three types of results. ${ }^{61}$ In some areas, regulation has actually ended up at a low level. The main example is the working and safety regulations on board ships. However, the phenomenon of flags of convenience (registering ships under the laws of a State with particularly low safety, labour, and environmental standards) hardly allows conclusions to be drawn about other areas of law. The shipping does not possess any fixed production site nor a territorial location for services, and also the crew members are universally mobile. Regulatory competition here builds on unique

\footnotetext{
Chap. ii 2 (26-27)).

55 Pope Benedict XVI. (2009, June 29). Encyclical Caritas in Veritate, para. 35.

${ }^{56}$ Kirchhof. Freiheitlicher Wettbewerb (note 5), 44.

57 The term "race to laxity" was coined in 1933 by U.S. Supreme Court Justice Louis Brandeis with regard to the competition among U.S. Federal States in the area of company law: "Companies were early formed to provide the charters for corporations in states where the cost was lowest and the laws least restrictive. The states joined in advertising their wares. The race was not one of diligence, but of laxity." U.S. Supreme Court, Ligget Co. V. Lee (288 U.S. 517, 558-559 (1933), footnotes omitted).

58 According to the German Monopolies Commission (Monopolkommission) (note 48), 23, the extent of the downward spiral is overestimated in the public debate.

59 Revesz, R. (1992). Rehabilitating Interstate Competition: Rethinking the Race-to-the-Bottom Rationale for Federal Environmental Regulation. NYU Law Review, 67, 1210-1254.

${ }^{60}$ On the non-existence of a downward spiral and on the shift of the burden of taxation Curzon-Price, V. (2008). Fiscal Competition and the Optimization of Tax Revenues for Higher Growth (pp. 155-182). In Bergh \& Höijer (note 12).

${ }^{61}$ Murphy, D. D. (2004). The Structure of Regulatory Competition. Oxford, NY: Oxford University Press, USA.
} 
features of the industry. Besides, flags of convenience are less a problem with regard to the contents and the level of protection and safety standards but rather with regard to the enforcement of those standards. A different question in this area of law concerns low taxes and low wages. Here, a downward spiral can be observed, particularly since long-established seafaring nations attempt to stimulate the re-flagging of ships by granting tax reliefs especially to ship owners. ${ }^{62}$

Another direction that legal competition can take is to produce agreement on a higher common denominator, the so-called "race to the top". This happened at the international level with, for example, the Montreal Protocol on protection of the ozone layer. ${ }^{63}$ An example of a "race to the top" at the domestic level is the "California effect", i.e. the introduction of higher exhaust emission standards in all U.S. Federal States and at the federal level according to the Californian model.

The third and by far the most frequent type of regulatory competition is the persistence of heterogeneity of the standards, despite competition. This is the case in broad areas of regulation, from the law on unfair advertising to animal welfare. This also applies regionally, as the example of Switzerland shows. Ever since the Swiss Federal State was founded in 1848, there has been competitive federalism with regard to many regulated professions. This competition has been enabled by free movement of professionals and the mutual recognition of Cantonal standards. Still, there is no "race to the bottom" here. ${ }^{64}$ The density and nature of the Cantonal regulations on diplomas, licences and permits to practise a profession obviously depend heavily on other factors, such as the influence of local interest groups and above all on regional cultural values. ${ }^{65}$ For example, professions in Protestant Appenzell Ausserrhoden are much less regulated than in Catholic Appenzell Innerrhoden, although labour and capital indeed moves between the two directly neighbouring Cantons. This means that regulatory competition exists - but has not led to uniform, let alone specifically low standards. ${ }^{66}$

In conclusion, no downward spiral per se can be generally attributed to competition between legal systems, and thus social (and environmental) principles are not jeopardised per se either.

\subsection{Competition between Legal Orders and the Public Interest}

The central objection raised to allowing competition between legal orders is the danger of neglecting the public (general) interest. ${ }^{67}$ This is because when designing his product, a supplier who is in competition focuses on the customers' needs and tries to satisfy specific customer groups.

But is a demand-oriented system really opposed to one that is geared to the public interest? There would not be any contradiction if the public interest were to result from the sum of individual preferences expressed, as it is assumed by utilitarianism. As Jeremy Bentham famously put it: "The interest of the community then is, what? the sum of the interests of the several members who compose it" " ${ }^{68}$ However, it has been demonstrated that it is impossible to reproduce faithfully the distribution of individual preferences of the members of a collective (e.g. of one nation) in democratic decision-making processes and reach one single decision at the same time. According to the Arrow theorem, it is logically impossible to design collective decision-making procedures which at least roughly meet minimum requirements for democratic procedures and which at the same time are consistent. In this sense, there is no "welfare function". ${ }^{69}$ This means that, for logical reasons alone, the pursuit of public-interest objectives cannot be confined to satisfying expressed individual preferences (signalled by "willingness to pay") of the "law consumer". (Nonetheless, decisions in the public interest may, without having recourse to an asserted "interest" of a non-existent, supra-individual entity, such as the "general public" or "society", strive for the fulfilment of assumed and widely shared interests and needs. ${ }^{70}$ )

\footnotetext{
${ }^{62}$ See on these issues König, D. (2009). Flags of Convenience. In R. Wolfrum (Ed.), Max Planck Encyclopedia of Public International Law. Oxford: Oxford University Press. Retrieved November 14, 2013, from http://www.mpepil.com.

${ }^{63}$ Montreal Protocol on Substances That Deplete the Ozone Layer (1987, September 16), revised version in United Nations Treaty Series (UNTS) (Vol. 1522), p. 3.

${ }^{64}$ De Chambrier, A. (2003). Die Verwirklichung des Binnenmarktes bei reglementierten Berufen, Grundlagenbericht zur Revision des BGBM (Bundesgesetz über den Binnenmarkt). Bern, Switzerland: Seco - Staatssekretariat für Wirtschaft.

${ }^{65}$ Feld, L. Regulatory Competition and Federalism in Switzerland (note 30), 24.

${ }^{66}$ Ibid., 23 .

${ }^{67}$ See Kirchhof, P. (Ed.) (2005). Gemeinwohl und Wettbewerb. Heidelberg, Germany: C.F. Müller.

${ }^{68}$ Bentham, J. (orig. 1789). An Introduction to the Principles of Morals and Legislation (Chap. I, Sec. IV, p. 3). Ed. (1948) by Lafleur, L. J. New York, NY: Hafner Publishing Company.

${ }^{69}$ Arrow, K. J. (1963, orig. 1951). Social Choice and Individual Value (2nd ed.) New Haven, Conn.: Yale University Press.

${ }^{70}$ Cf. Weale, A. (1998). Public Interest. In E. Craig (Ed.). Routledge Encyclopedia of Philosophy (Vol. 7, pp. 832 et seq. (p. 834)). London,
} 
Generally speaking, public-interest considerations must combine concerns of effectiveness and of equity. On the one hand, they take as their starting point actual particular preferences of individuals; on the other hand, the real or presumed interests of the group are sometimes allowed to prevail. ${ }^{71}$ It is precisely this tension between the individual preferences and the collective interest that characterises the concept of public interest. That is why the procedures for resolving this tension in the concrete case are key. Generally accepted formal principles which safeguard the "production" of fair public interest decisions are the rules of neutrality, unselfishness, administrative restraint and responsibility, the ex-ante-circumscription of competences and procedures, modalities of control, and transparency.

Pure competition is not a suitable method for resolving this tension. This is because competition merely creates an advantageous legal order for those individuals who hold a powerful market position in the light of whatever aims and interests they actually pursue. Therefore, competition between legal orders must be supplemented by other control mechanisms and, where appropriate, be corrected to create a legal system in the public interest.

\section{Embedding Legal Systems Competition in a Meta Order}

The normative assessment of competition between legal orders in the light of constitutional principles offers a guideline for the legislative response to that competition, i.e. guidance for how to appropriately frame that competition legally.

\subsection{Are There General Legal Principles which Call for Entering into Regulatory Competition?}

Competition is not an end in itself. Nor can any legal obligation which allows or promotes competition between legal orders be derived from general legal principles. Neither State sovereignty, nor federal guarantees of the existence of federal States, ${ }^{72}$ nor the subsidiarity principle ${ }^{73}$, nor the European fundamental freedoms ${ }^{74}$ together with the country-of-origin-principle can be interpreted as requiring competition as a matter of legal principle.

The same is true for the legal concept of private autonomy. From a continental European perspective, private autonomy justifies the principle of freedom of choice in private international law and thus is a functional condition of legislatory competition. ${ }^{75}$ However, this justification holds only as far as third-party interests are not affected. When it comes to law-making, third parties will inevitably be affected. Therefore, the concept of private autonomy does not in itself justify or require any State to provide for choice-of-law-rules which in turn are conducive of a specific type of legal competition.

All mentioned principles (pertaining to international, European, and the domestic law of many States) are merely conditions for the possibility of legal competition, but not its normative basis. Hence, the idea of embedding the fact of regulatory competition into legal standards does not flow from any legally binding obligation to ensure such competition.

Only if the competition of legal orders actually safeguards freedom, compensates for shortcomings in the democratic process and generates wealth, the "principle" of competition might be considered as a kind of secondary or auxiliary legitimising principle which may guide legal policy. Obviously, the competition of legal orders cannot justify the adoption of legal rules and instruments which would otherwise be unconstitutional. Thus, the answer to the second question asked in the introduction, that is, whether the promotion of the competition between legal orders may serve as a normative guideline for the national and supranational legislator and for other State activity is in principle: yes it may, but it need not. The law allows the promotion of competition between legal orders, but does not prescribe it.

\footnotetext{
England: Routledge.

${ }^{71}$ Koller, P. (2002). Das Konzept des Gemeinwohls. Versuch einer Begriffsexplikation. In W. Brugger et al. (Eds.), Gemeinwohl in Deutschland, Europa und der Welt (pp. 41-70, (pp. 50-52)). Baden-Baden, Germany: Nomos.

${ }^{72}$ See Art. 79 sec. 3 and Art. 29 sec. 3, sentence 4 of the German Basic Law (Grundgesetz, GG); Art. 53 Swiss Federal Constitution; Art. 4 sec. 3 of the U.S. Constitution.

${ }^{73}$ See however for the principle of subsidiarity as the "quest for a maximum of competition between the legal orders" Kerber, W. (1998). Zum Problem einer Wettbewerbsordnung für den Systemwettbewerb. Jahrbuch für neue politische Ökonomie, 17, 199 et seq. (207) (author's translation).

${ }^{74}$ See on this Terhechte, J. P. (2009). Wettbewerb der Regulierungen als Integrationsstrategie der Europäischen Union? In H.-J. Blanke et al. (Eds.), Dimensionen des Wettbewerbs - Europäische Integration zwischen Eigendynamik und politischer Gestaltung (pp. 74-98). Tübingen, Germany: Mohr Siebeck.

${ }^{75}$ See below note 82 .
} 
De lege ferenda, the (meta) legal order should be designed in such a way that the competition of legal orders develops, but is also controlled, guided and under certain circumstances curtailed, in order to strengthen its positive impact on the implementation of constitutional principles and to contain the negative effect on them. The aim is thus the creation of an "order for competition [Wettbewerbsordnung]" as defined by ordo-liberalist Walter Eucken. ${ }^{76}$

Such a legal meta order requires two sets of meta rules: first of all, those that make competition between legal systems possible, ensure its existence and, if necessary, enhance that competition. This set of rules can be described as law constitutive of competition. The second set consists of rules that counteract as far as possible the harmful repercussions of competition between legal systems. The regulatory objective of these competition rules must be to prevent as far as possible "unfair" competition between legal orders. "Unfairness" is measured by means of constitutional principles which are generally acknowledged in the national and supranational realm.

\subsection{The Meta Order Constituting Competition}

The body of law establishing competition must first of all contain rules for the so-called parallel process in competition, that is, for the relationship between the different law-providers. Those rules are, for instance, those which guarantee that a multiplicity of law-makers persists, because there can of course be no competition when only one single supplier exists as a monopolist. The principle of sovereignty and federal principles do indeed guarantee that a multiplicity of potentially law-"offering" actors co-exist. ${ }^{77}$ Also, legal rules on the allocation of law-making competencies regulate the relationship of different law-providers amongst themselves. These rules thus also relate to the parallel process of competition.

Secondly, the direct and indirect choice-of-law-modalities already addressed in the analytical part of this paper (section 4) must be guaranteed in the exchange relationship in order for competition to flourish. We have seen that these modalities are mainly democratic elections, freedom of migration, freedom of choice of law in private international law and free movement of goods.

Free movement of workers is not guaranteed in international law. And in spite of the WTO, trade in goods and services has only been partially deregulated. Essentially, GATT and GATS have merely removed non-tariff barriers to mobility. Other barriers - such as tariffs - are being gradually reduced qua negotiation processes. Moreover, measures that hamper the free movement of goods and services, but which are justified to protect national public interests, remain permissible (Art. XX GATT, Art. XIV GATS). Capital movements have even less been deregulated: the international flow of capital, except for payment transactions, is not free. Sovereign States may restrict these flows ( $c f$. Art. IV (1) and (3) IMF-Agreement). Under Art. XXX (d) IMF-Agreement, only payment transactions (but not other forms of capital flows) are privileged. The WTO does not foresee the general liberalisation of capital flows either but again only of payment transactions (Art. XI GATS). ${ }^{78}$ To conclude, some of the core legal conditions which would be necessary to establish a genuine competition of legal systems are lacking at the international level.

Within the EU and associated States such as Switzerland, ${ }^{79}$ "entry/exit rules" have only been guaranteed by the basic Union freedoms (free movement of workers, free establishment, free movement of goods, services) since that moment when those freedoms have been construed in the case law and in legal practice as so-called prohibitions on Member State restrictions of these freedoms. In the early days of the EU, those basic freedoms had been more narrowly understood to guarantee only non-discrimination (in relation to the regulating Member State's own nationals). In that phase, the basic EU freedoms did not yet automatically guarantee mobility, because the standards of the country of origin and the country of destination had to be complied with cumulatively (e.g. by the businessman who sought to establish a residence in another Member State). Even today, those Member States' restrictions on basic freedoms which are allowed in order to protect overriding (domestic) public interests under EU-law continue to constitute barriers to mobility. And these barriers in turn hinder

\footnotetext{
${ }^{76}$ Eucken, W. (1990/1952). Grundsätze der Wirtschaftspolitik (6th ed.). Tübingen, Germany: Mohr Siebeck, 245-250.

${ }^{77}$ See above note 72 .

${ }^{78}$ See Ruffert, M. (2009). Free Flow of Capital. In R. Wolfrum (Ed.), Max Planck Encyclopedia of Public International Law. Oxford, England: Oxford University Press 2009, Retrieved November 14, 2013, from http://www.mpepil.com.

79 The free movement of persons is guaranteed by the agreement between the European Community and its Member States, and the Swiss Confederation, on the free movement of persons of 21 June 1999 (SR 0.142.112.681). See for the "autonomous adoption" (i.e. copying) of the EU's country-of-origin-rule for technical norms and standards by Switzerland, including the "Cassis de Dijon" exception for the protection of overriding public-interest-objectives (see note 80) the Swiss Federal Act on Technical Barriers to Trade (Bundesgesetz über die technischen Handelshemmnisse, THG) of 25 June 2009, Bundesblatt 2009, 4463 (insertion of sec. 16a THG in 2009).
} 
competition between legal orders. ${ }^{80}$ Furthermore, harmonisation of the domestic law of the Member States, as far as it goes, excludes competition between legal orders. This means that competition between Member States' laws in the EU is only a residuum of the regulatory leeway the Member States are left with once they have complied with the prohibitions on restrictions of basic freedoms on the one hand, and with the obligation to harmonise their law on the other hand. ${ }^{81}$

As a result, a trade-off exists with regard to the conditions of legal diversity and factor mobility. Diversity of legal orders is the prerequisite for competition between those systems. On the other hand, this legal diversity itself is a barrier to mobility, while mobility in turn is likewise a prerequisite for legal competition. It is impossible to optimise both functional conditions at the same time - full diversity of law and unhampered mobility. The improvement of one condition inevitably deteriorates the other.

\section{3 (Re-)Restriction of the Selection Modalities?}

The second set of rules for regulating or taming legal competition consists of legal barriers to unfair, excessive and otherwise harmful competition between legal orders. I will focus on two main strategies: first, (re-)restriction of the selection modalities, and second, rules of fair competition.

Some of the modalities of direct and indirect choice of law can be considered as an outgrowth of legal or even constitutional guarantees of freedom. For example, freedom of choice under conflict-of-law-provisions particularly in contract law - is in continental Europe regarded as an expression of private autonomy and of the constitutional liberty of citizens. ${ }^{82}$ Some consider freedom of choice as being required by customary international law and even as a necessary consequence of the basic freedoms of the single European market. Indeed, allowing a company to choose one legal order for all its subsidies facilitates the firm's mobility and therefore seems to honour the EU-guarantee of freedom of establishment. On the other hand, the choice-of-law-option can be compared to a "selling modality" in this sense of the ECJ's Keck-decision, ${ }^{83}$ which would mean that the choice of law does not even come within the scope of the EU fundamental freedom in the first place. Hence, a Member State's restriction of the freedom to choose the law does not always imply a potential curtailment of EU basic freedoms.

This issue is viewed differently in the Common law tradition. In the Common law, party autonomy with regard to the choice of the applicable substantive law and with regard to the choice of the forum has only been accepted alongside with the European harmonisation of private international law (choice-of-law-rules) ${ }^{84}$ The same view has been espoused by the French doctrine of objective connection regarding contractual obligations. ${ }^{85}$ Seen from the viewpoint of both the latter, the options for choice under conflict-of-law-provisions could in theory be restricted again without violating the basic private law principle of party autonomy. Such a restriction does however not seem likely in real life, it would run counter current legal trends.

We have seen that the second choice-of-law-modality was the "exit"-type modality. Here we must distinguish the two variants mentioned above (section 4.2.2.), and their use by natural persons and corporate entities. The first variant, change of nationality by natural persons - that is, the exit by citizens from their State - may not be categorically prohibited in an open society. For example, Art. $15 \mathrm{sec} .2$ of the Universal Declaration of Human Rights of 10 December 1948 stipulates: "No one shall be arbitrarily deprived of his nationality nor denied the right to change his nationality". ${ }^{86}$ However, "openness" of a society by no means requires that natural persons must be allowed to change their nationality at will any time. Restrictions on the choice of nationality, imposed by both the releasing State and the naturalising State, in particular through the requirement of a minimum period of residence and a domicile in the new State, are permissible.

\footnotetext{
${ }^{80}$ See as an example for limitations of the free movement of goods Art. 36 TFEU (ex-Art. 30 EC Treaty) and ECJ, case 120/78, Rewe v. Bundesmonopolverwaltung für Branntwein (“Cassis de Dijon”), ECR 1979, 649.

${ }^{81}$ Teichmann, C. (2006). Binnenmarktkonformes Gesellschaftsrecht. Berlin, Germany: de Gruyter Recht, 383.

${ }^{82}$ Institut de droit international (1991, August 31). Resolution "L'autonomie de la volonté des parties dans les contrats internationaux entre personnes privés" Retrieved November 14, 2013, from www.idi-iil.org.

${ }^{83}$ ECJ, joined cases C-267/91 and C-268/91, Criminal proceedings against Bernard Keck and Daniel Mithouard, ECR 1993 I-06097.

${ }^{84}$ Mills, A (2009). The Confluence of Public and Private International Law (pp. 292-93). Cambridge, England: Cambridge University Press.

${ }^{85}$ See seminally Battifol, H (1960). Subjectivisme et objectivisme dans le droit international privé des contrats, In Faculté de droit et des sciences économiques de Toulouse (Ed.), Mélanges offerts à Jacques Maury (Vol. 1, pp. 39-58), Paris, France: Librairie Dalloz et Sirey.

${ }^{86}$ To the same effect Art. 8 of the European Convention on Nationality of 6 November 1997, ETS no. 166.
} 
The choice of the law applicable to moral persons, especially corporations, may be regulated as well. So the conversion of a company incorporated under the law of one EU-Member State into a company governed by the law of a second Member State may be regulated by that second Member State. ${ }^{87}$

"Exit" through emigration (without a change of nationality) is likewise guaranteed as a basic or human right. ${ }^{88}$ Within the EU, emigration is additionally guaranteed as a basic European freedom (freedom of movement of workers and freedom of establishment). Bans on leaving a country for natural persons along the lines of the former German Democratic Republic annihilate this right and constitute blatant human rights violations.

A different question is the admissibility of indirect restrictions of the basic rights or basic freedoms, as it is found, for example, in the levying of a departure tax. Examples are the Russian "diploma tax", the "Bhagwati" tax for the compensation of the "brain drain" from developing countries as well as the "exit taxes" in some States. ${ }^{89}$ Here one would have to discuss, first, whether such a tax may be established in conformity with the concept of taxation. Justifying the imposition of a tax on a particular person by pointing to the taxed person's prior utilisation of the State's infrastructure or to him or her having received social welfare benefits preceding the emigration does not appear to be in conformity with the idea of taxation. It is not in conformity because it would thwart the basic idea that tax obligations are independent from specific benefits received by the State. Another possible justification of exit taxes, namely levying them solely on the basis of a person's nationality, appears to be problematic from the public international law perspective. In any case, such a tax would have to be applied without discrimination which means that it could not be imposed on emigrants only. ${ }^{90}$

From the viewpoint of constitutional, international, and EU-law, the question is under which conditions and in which constellations the restriction of basic rights or basic freedoms effected by such a departure tax would exceptionally be justifiable as a defensive measure in the competition between legal orders, in particular with regard to moral persons in order to protect overriding public interests. According to the European Court of Justice (ECJ), French taxes which were charged on increases in value of company securities when a taxpayer transferred his tax residence outside France unduly restricted the freedom of establishment. The objective of preventing tax evasion could be achieved by measures that are less coercive or less restrictive of the freedom of establishment, for example, by providing for the taxation of taxpayers returning to their home country after realising their increases in value during a relatively brief stay in another Member State. Such a taxation would apparently be compatible with the freedom of establishment. The structural difference between the basic freedoms under EU-law and the fundamental right to emigrate does not seem to play a role in this context. ${ }^{91}$

One could argue further that the selective "exit" of more or less virtual parts of large companies to save on taxes does not even come within the scope of the right to leave the country or the right to business or freedom of contract or establishment. This would mean that an EU Member State's attempt to prevent such "exit" would not constitute a violation of the EU fundamental freedoms. Or, such a business design could possibly be qualified as an abuse of those basic rights or freedoms. Then, the company would be precluded from relying on the EU freedom establishment, and Member States could lawfully restrict or prevent their "exit", too. (This argument has however not been accepted by the ECJ, which in Cadbury Schweppes held that the establishment of a company in a Member State for the purpose of benefiting from more favourable (tax) legislation does not in itself suffice to constitute an abuse of the freedom of establishment. ${ }^{92}$ )

These possible legal strategies to prevent business exits are, however, difficult to implement from a legal and factual point of view, regardless of their economic rationality (or lack of rationality). The policy focus should be placed on reducing the incentive to vote against a legal system. This means, in principle, facing up to competition between legal systems.

\footnotetext{
${ }^{87}$ Cf. obiter dictum in ECJ, case C-210/06, Cartesio (note 34), paras 111-112.

${ }^{88}$ Art. $13 \mathrm{sec} .2$ Universal Declaration of Human Rights; Art. 12 ICCPR; Art. 2 sec. 2 of Prot. No. 4 to the ECHR.

${ }^{89}$ See Schön, W. Steuerstaat und Freizügigkeit. In Becker \& Schön (note 13), 41 et seq. (46-50) with further references.

${ }^{90}$ See ibid. 60-74.

${ }_{91}$ ECJ, case C-9/02, Hughes de Lasteyrie de Sailant, ECR 2004, I-2409, paras 38-54.

92 ECJ, case C-196/04, Cadbury Schweppes v. Commissioners of Ireland Revenue, judgment of 12 September 2006 (Grand Chamber), paras 35-38. According to ECJ, Centros (note 34), para. 27, "the fact that a national of a Member State who wishes to set up a company chooses to form it in the Member State whose rules of company law seem to him the least restrictive ... cannot, in itself, constitute an abuse of the right of establishment."
} 


\subsection{Identification of Unfair Regulatory Practices}

In practice, the most important strategy for guiding competition between legal orders are the rules on fair competition. We must first form an idea which competitive actions taken by law-providers can reasonably be deemed "unfair". In order to determine this, one has to gain a clear idea of the goods to be protected. From a constitutional perspective, the goods to be protected are the above-mentioned constitutional principles.

\subsection{1 "Harmful" Tax Competition}

Unfair regulatory practices have been discussed up to now mainly in relation to competition between tax regulations. ${ }^{93}$ At the end of the 1990 s, packages of measures were devised in the context of the $\mathrm{OECD}^{94}$ and the $\mathrm{EU}^{95}$ against so-called harmful tax competition. The idea of "harmful tax regimes" is difficult to grasp in legal terms. The OECD-report defines harmful preferential tax regimes by four key factors: ${ }^{96}$ first, when a State imposes no or very low tax rates; second, the "ring fencing" of regimes; third, the lack of transparency in the operation of a regime; and fourth, the lack of effective exchange of information. ${ }^{97}$ According to the OECD, a State may be qualified as a tax haven also when it does not require actors which seek to come under its (tax) jurisdiction to perform any substantial economic activity within the State itself. ${ }^{98}$ Finally, the OECD gives the following auxiliary criteria for the determination whether a legal tax regime is "harmful": when the tax base is defined artificially; when the regime fails to adhere to international transfer pricing principles; when it exempts foreign source income from the residence country tax; when the tax rate or tax base is negotiable; where there exist bank secrecy provisions; when the country offers access to a wide network of tax treaties (which may enhance the benefits of harmful preferential tax regimes); or when the regime is promoted as a tax minimisation vehicle. ${ }^{99}$ The EU-code of conduct for business taxation of 1997 qualifies, in a slightly different terminology, the same measures as "harmful" as the OECD. ${ }^{100}$

Taxation policies reflect different, culturally conditioned views. Against this background it is difficult to define the point at which the legitimate exercise of taxation sovereignty turns into unfair "poaching" on foreign tax territory. The limit must be determined by means of various factors, and here the criteria formulated by the OECD and the EU are only a first approach. Furthermore, we must note that there are different degrees of harmfulness. Finally, there may be reasons for justifying certain tax measures, in particular a State's need to compensate for natural locational disadvantages. ${ }^{101}$ For example, Art. 107 sec. 3 lit. a) TFEU declares as compatible with the common market aids to promote the economic development of areas where the standard of living is abnormally low or where there is serious underemployment, and with a view to the structural, economic and social situation of certain regions.

\subsubsection{Unfair "Regulatory" Subsidies?}

Generally speaking, legal practice and courts should first of all seek to draw up unambiguous criteria for defining unfair or harmful regulatory practices. Otherwise a meta order for legal competition would not be operational. In order to determine whether a legal regime is "unfair", one might have recourse to the characteristics established within the EU for unallowable and allowable subsidies and those subject to

\footnotetext{
${ }^{93}$ See in State practice on combating "unfair" tax competition the respective provisions in double taxation agreements, e.g. Art. 28 sec. 2 of the double taxation agreement Germany - Austria of 24 August 2000: "Der Ansässigkeitsstaat ist berechtigt, seine innerstaatlichen Rechtsvorschriften zur Abwehr von Steuerumgehungen anzuwenden, um missbräuchlichen Gestaltungen oder unfairem Steuerwettbewerb zu begegnen." ("The country of residence is entitled to apply its domestic provisions against tax avoidance in order to deal with abusive legal constructs or unfair tax competition", translation by the author).

94 See OECD (1998). Harmful Tax Competition: An Emerging Global Issue. Paris, France: OECD. The OECD differentiates between "tax havens" and (merely) "harmful preferential tax regimes". Subsequently, as part of the "OECD Project on Harmful Tax Practices", progress reports were published on a regular basis (of 2000, 2001, 2004 and 2006). See also "Overview of the OECD's Work on Countering International Tax Evasion" of 16 September 2009.

${ }_{95}$ Conclusions of the Ecofin Council Meeting on 1 December 1997 concerning taxation policy (OJ EC 1998/C 2/01 et seq.); Annex 1: Resolution of the Council and the Representatives of the Governments of the Member States, Meeting Within the Council of 1 December 1997 on a code of conduct for business taxation (OJ EC 1998, C 2/02 et seq.).

${ }^{96}$ OECD 1998 (note 94), paras 57-84; summary in ibid., 27, box II.

${ }^{97}$ See on the last criterion the critical statements of Switzerland and Luxembourg in the annex of the OECD-report 1998, 76 et seq.

${ }^{98}$ Summary in OECD 1998, 23, box I.

${ }^{99}$ Ibid., paras 68-79.

${ }^{100}$ See Art. B of the code of conduct (note 95).

${ }^{101}$ Cf. OECD 1998 (note 94), paras 31 and 27.
} 
approval. ${ }^{102}$ Within the EU, the State aid prohibition rule as laid down in Art. 107 TFEU (ex-Art. 87 EC Treaty) is in fact already applied to those preferential taxes that threaten to distort competition. ${ }^{103}$

However, determining that a specific regulation is equal to a subsidy (a subsidy in form of laws, without giving any money) would have to be based upon very complex political considerations. Currently, no consensus exists about this matter at the international level. ${ }^{104}$ The intention and purpose of the legal prohibitions on (traditional, financial) subsidies are such that they seem hardly applicable to competition between legal systems. It is therefore difficult to tackle regulatory competition within the legal framework of subsidies.

\subsubsection{Normative Dumping?}

The existing WTO anti-dumping provisions ${ }^{105}$ against the alleged under-regulation of certain areas of law, polemically known as "normative dumping" or "ecological and social dumping" cannot be applied here. A product is, according to the legal definition given in Art. 2 of the Antidumping Agreement, ${ }^{106}$ "dumped", when it is "introduced into the commerce of another country at less than its normal value", that is when "the export price of the product exported from one country to another is less than the comparable price, in the ordinary course of trade, for the like product when destined for consumption in the exporting country".

Because the discrepancy in wages and social or environmental standards is a normal consequence of the market mechanism, it is controversial whether the elimination of this competitive advantage of "low-wage-countries" is desirable or should on the contrary be prohibited on the ground that it is in reality a protectionist strategy of the industrialised countries. Given this uncertainty, even the concept of normative dumping is not currently one on which a consensus could be reached. Anti-dumping law is thus not applicable to competition between legal systems.

\subsubsection{Non-Regulation of Inhumane Production Conditions}

The counterexample is the State's toleration of forced labour. ${ }^{107}$ This is an unfair practice in competition between legal orders. It is unfair because a locational advantage is based on inhumane production conditions. Between a competitive advantage that has to be accepted and clearly unfair forced labour there is a broad grey area of employment relationships and working conditions, the "fairness" of which is questionable. A distinction should be drawn here between occupational safety and health and accident prevention on the one hand and wages and protection against unfair dismissal on the other. Overly lax regulation in the former area should be qualified as an unfair regulatory practice in competition between legal orders for production locations. Because of varying societal expectations regarding health and security, the threshold beyond which conditions are "unfair" does not need to be identical everywhere on the world. This graduation is being taken into account by the International Covenant on Economic, Social and Cultural Rights. The contracting parties are only required to "achieve the full realization" of the right to safe and healthy working conditions "progressively" ${ }^{108}$ Standards on work safety and hygiene are clearly unfair when the local legal system would qualify them as violative of personal rights of workers.

\subsection{Elements of the Quality-Ensuring Meta Order}

The meta order for curbing the negative repercussions of competition between legal orders would have to contain a number of general elements.

Rules of international cooperation: the meta order would, firstly, have to establish international cooperation on combating unfair practices. ${ }^{109}$ An example from the area of taxation is the OECD's strategy for improving transparency and information exchange. ${ }^{110}$

\footnotetext{
${ }^{102}$ Art. 107 sec. 1 TFEU. See for the WTO Art. XVI GATT and the WTO Agreement on Subsidies and Countervailing Measures (1994, April 15) (OJ 1994 L 336/156).

${ }^{103}$ ECJ, case C-172/03, Heiser, ECR 2005, I-1627, esp. para. 27.

104 Trachtman, J. (1993). International Regulatory Competition, Externalization, and Jurisdiction. Harvard International Law Journal, 34, at 47,50 and 91.

105 Art. VI GATT and the Agreement on Implementation of Article VI of the General Agreement on Tariffs and Trade 1994 ("Antidumping Agreement”), OJ 1994 L 336/ 103, implemented in the EU by Regulation No. 384/96, OJ EC 1996, L 56/1.

106 Note 105.

${ }^{107}$ Prohibited under Art. 4 ECHR; Art. 8 sec. 3 CCPR.

${ }^{108}$ See Art. 2 sec. 1 and 2, Art. 7 lit. b) and 12 sec. 2 lit. b) ICSECR.

109 See in favour of a multilateral approach to combating unfair tax competition Avi-Yonah. Welfare State (note 40).

${ }^{110}$ See the OECD-Document (2009, September 16). Overview of the OECD's Work on Countering International Tax Evasion. One of the
} 
Rules for selective intensification of legal order competition: the quality-ensuring meta order could also selectively seek to intensify competition. This could be done, for example, by broadening the direct choice-of-law-options in private international law. If low standards can be voted out by those people or entities who are put at a disadvantage by them, a "race to the top" will be set in motion. For example, the EU-Regulation on the law applicable to non-contractual obligations ${ }^{111}$ allows the victim a choice of law for environmental damage caused at multiple locations. ${ }^{112}$ This grants persons who have suffered damage access to higher environmental standards and is thus suitable to set in motion a race to the top.

Regulation by civil society: furthermore, the meta order of legal systems competition would have to overcome the dichotomy of State versus market, for example, by recognising civil society as a third force. ${ }^{113}$ Civil society groups exert an influence on the further development of legal systems in a way that is different both from the sovereignty mode of action and from the competition mode. What is known as "civil regulation" results from an interaction between private, social and governmental players. ${ }^{114}$ When acting in the form of civil regulation, specific legitimacy deficits of the participating groups (for example each group's bias) might to some extent cancel each other out (or neutralise each other). Thus, civil regulation could be promoted and designed in a way so as to contribute to ensuring fair competition between legal systems.

Conflict resolution rules: finally, the meta order would have to provide for conflict resolution mechanisms to ensure the quality of legal systems competition. One example is the special, consultative, non-adversarial conflict resolution mechanisms that exist in EU-law - but which have never been used to date - for provisions of national law of Member States that distort the conditions in the internal market. ${ }^{115}$

\subsection{Selective Harmonisation of Law}

It has been asserted that competition of the laws spontaneously and gradually brings about the exactly preference-matching degree of a "natural" convergence of laws. If that assertion were correct, concerted, formal agreements or centralised obligations of legal harmonisation would be superfluous, and an over-excessive levelling down could be avoided, too. In contrast to a deliberate top-down harmonisation, the assumed "bottom-up" convergence brought about by competition would not be formally fixed, and it would thus remain flexible and reversible. Under this assumption, the result of the competition of differing legal regimes would ultimately be its own abrogation. The reason is that the final stage of legal convergence would amount to an annihilation of the freedom of choice of laws, and the concomitant incentives to improve the laws supplied would also disappear.

However, competition does not seem to bring about any "natural" convergence of the law. In fact, in legal areas with a high degree of competition, e.g. in contract or company law, a "natural" convergence is not discernible. ${ }^{116}$ This is not surprising, because a convergence could only be expected if the majority of law-customers showed the same preferences on norms. This is only the case for so-called "homogeneous", i.e. neutral norms. ${ }^{117}$

indispensable procedural features of this cooperation is meanwhile the supply of information on request (cf. Art. 26 OECD-Model Tax Convention on Income and on Capital of 17 July 2008 (http://www.oecd.org/dataoecd/43/57/42219418.pdf)). Since the withdrawals of the "reservations" on Art. 26 Model Convention by Switzerland, Belgium, Luxemburg, and Austria, all OECD Member States accept the principle of supplying "foreseeably relevant" information "on request", which can be refused on ordre-public-grounds.

${ }^{111}$ Regulation (EC) No 864/2007 of the European Parliament and of the Council of 11 July 2007 on the law applicable to non-contractual obligations ("Rome II").

112 Art. 7 of the Regulation (Environmental Damage) runs: “The law applicable to a non-contractual obligation arising out of environmental damage or damage sustained by persons or property as a result of such damage shall be the law determined pursuant to Article 4(1), unless the person seeking compensation for damage chooses to base his or her claim on the law of the country in which the event giving rise to the damage occurred."

${ }^{113}$ See Hannah Arendt's differentiation between the public, private and social sphere, which anticipated the rise of civil society already 50 years ago (Arendt, H. (1958). The Human Condition (pp. 35-45). Chicago, IL: University of Chicago Press).

114 Peters, A., Förster, T., Koechlin, L. (2009). Towards Non-state Actors as Effective, Legitimate, and Accountable Standard Setters. In A. Peters et al. (Eds.), Non-state Actors as Standard Setters (pp. 492-562). Cambridge, England: Cambridge University Press.

115 Art. 116 and 117 TFEU (ex-Articles 96 and 97 EC). Art. 116 TFEU: "Where the Commission finds that a difference between the provisions laid down by law, regulation or administrative action in Member States is distorting the conditions of competition in the internal market and that the resultant distortion needs to be eliminated, it shall consult the Member States concerned." See in favour of applying these rules for settling disputes over on tax competition Schön. Steuerwettbewerb in Europa (note 40), 358.

${ }^{116}$ See for company law in Europe Bratton, W. W., McCahery, J. A., Vermeulen, E. P. M. (2009). How Does Corporate Mobility Affect Lawmaking? A Comparative Analysis, American Journal of Comparative Law, 57, 347-385.

117 Seminally Ogus, A. (1999). Competition between National Legal Systems: A Contribution of Economic Analysis to Comparative Law, 
However, this type of norms is scarce, for even seemingly neutral norms, such as rules on formalities and procedures, tend to favour some interests and particular parts of society while being rather disadvantageous to others.

In the absence of a "natural" convergence, an essential component of the meta order of legal systems competition must be selective harmonisation of law. This is not necessarily a hindrance to or suppression of the competition of rule-makers, but may intensely contribute to creating and embedding such competition. ${ }^{118}$ The selective harmonisation should concern, firstly, procedures. First and foremost, the rules on information should be uniform. Informed decisions are an essential precondition for an unimpaired competition of legal systems triggered through "exit", because information which is easily available helps to reduce mobility costs. ${ }^{119}$ Secondly, in order to prevent legal standards from falling below a tolerable level, the aim should be the harmonisation of substantive standards at a minimum level, in particular in the areas of occupational safety and environmental standards. ${ }^{120}$ For example, in the EU, technical standards are being harmonised under a "new approach". Here legislative harmonisation is confined to laying down the essential requirements, conformity with which will entitle a product to free movement within the Union. The harmonisation is realised by private-public standards bodies upon consultation of all societal groups likely to be affected (e.g. consumers), and with the assistance of the EU Commission. ${ }^{121}$ Beyond such minimal harmonisation, a competition of standards persists. ${ }^{122}$ Another example is the international harmonisation of the rules on the determination of the taxable base - as opposed to the determination of the tax scale (i.e. the rates and the progression) which should be left to the mechanisms of competition. ${ }^{123}$

As long as international harmonisation agreements are rescindable, the participating States will be able to denounce them and thereby retain residual control. Thus, "vertical competition" (between the supra-national harmonised regime and the national regime) will continue to be operative. The upcoming research task is to identify variables to achieve the optimal mix between legal competition and cooperation. ${ }^{124}$

\section{Conclusion: Competition and Human Dignity}

The answer to the analytical question raised in this paper is that the description of the evolution of legal order in terms of "competition" does convey some analytical benefit. We can meaningfully say that there is competition between legal orders. That competition is incomplete, however, particularly because the competitive cycle is often interrupted by weak selection pressure and due to selection inaccuracy.

My normative analysis of this regulatory competition has used some legal (even constitutional) principles as benchmarks, namely liberty, equality, democracy, the social principle and the public interest. The assessment of the suitability of legal systems competition, considered as a possible process for securing freedom, democracy, and so on, and of the way in which said competition can be framed by a meta order, depends on the conception that the observer forms of the State and of the democratic process. Anyone who thinks that the State which furthers the public interest is a myth anyway ${ }^{125}$ will rate on the high side the freedom- and equality-promoting and solidarity-facilitating potentials of competition between legal orders, and will view competition as a useful corrective measure against excessive taxation and regulation. However, the purely sociological finding that the State and the democratic process are necessarily "captured" by certain interest groups is in conflict with the legal analysis which postulates that the State and democracy are normative concepts and thus to a certain extent counterfactual. The argument of "capture" therefore carries only limited weight in the juridical discourse.

Constitutional lawyers recognise the fundamental ambivalence of the State, which on the one hand is able to contain the war of all against all, but which on the other hand can, as an untamed Leviathan, bring about intolerable injustice. Given this fundamental ambivalence, competition between States and their legal orders over

ICLQ, 48, 405 et seq.; see also Muir-Watt. Aspects économiques (note 26), 79-82.

118 Teichmann. Gesellschaftsrecht (note 41), at 386.

119 Ibid., 385-86.

${ }^{120}$ See for minimal harmonisation in the field of environment Articles 192-193 TFEU (ex-Art. 175-176 EC).

${ }_{121}$ Completing the Internal Market: White Paper for the Commission to the European Council (28-29 June 1985), COM (85) 310 final (1985), paras 67-73.

${ }^{122}$ See for a prohibition of harmonisation Art. $153 \mathrm{sec} .2$ lit. a) TFEU (ex-Art. $137 \mathrm{sec} .2$ EC Treaty).

${ }^{123}$ Gerken, Märkt, Schick. Steuerwettbewerb (note 40), at 266.

${ }^{124}$ Esty, D., Geradin, D. (2000). Regulatory Co-opetition, Journal of International Economic Law, 3, 235-255; Trachtman, J. (2008). The

Economic Structure of International Law (pp. 62-63). Cambridge, MA: Harvard University Press,.

${ }^{125}$ Cf. Buchanan, J. M. (2003). Public Choice: Politics without Romance, Policy 19/no. 3, 13 et seq. 
their product "law" should be understood (and built up) as process which is complementary to the traditional legal devices for guaranteeing the fundamental principles: liberty, equality, democracy, solidarity and orientation at the common good of a given society. Competition can function in such a complementary way if it is meaningfully integrated into a competition order.

A fundamental component of this competition order is to safeguard respect of inalienable legal principles. Inalienability means that the principles are to be respected regardless of anyone's willingness to "pay" for their respect, a willingness which would manifest itself primarily in "voice" or non-"exit". These principles must remain legally protected as a fixed point, independently of and transcending competition between legal orders. The reason is that they are things - to quote Kant $^{126}$ - that do not have a price, but a dignity.

\section{Acknowledgement}

I wish to thank the anonymous reviewers for useful comments on the initially submitted version of the manuscript. The paper develops further ideas first presented in: Peters, A. (2010). Wettbewerb von Rechtsordnungen. In Veröffentlichungen der Vereinigung der Staatsrechtslehrer 69 (Ed.), Gemeinwohl durch Wettbewerb? (pp. 7-56). Berlin, Germany: de Gruyter.

\section{Copyrights}

Copyright for this article is retained by the author(s), with first publication rights granted to the journal.

This is an open-access article distributed under the terms and conditions of the Creative Commons Attribution license (http://creativecommons.org/licenses/by/3.0/).

\footnotetext{
126 "In the realm of ends everything has either a price or an intrinsic value. Anything with a price can be replaced by something else as its equivalent, whereas anything that is above all price and therefore admits of no equivalent has intrinsic value." Kant, I. (orig. 1785, 1999). Groundwork of the Metaphysics of Morals. Cambridge, England: Cambridge University Press, at 33. Note that the German original uses the term: 'Würde' (dignity), not "intrinsic value".
} 